\title{
Newborn Serum Retinoic Acid Level Is Associated With Variants of Genes in the Retinol Metabolism Pathway
}

\author{
DANIEL C. MANOLESCU, REYHAN EL-KARES, LAJMI LAKHAL-CHAIEB, ALEXANDRE MONTPETIT, PANGALA V. BHAT, \\ AND PAUL GOODYER
}

\begin{abstract}
Department of Medicine [D.C.M., P.V.B.], University of Montreal, Montreal, Quebec, H2W 1T8, Canada; Department of Pediatrics [R.E.-K., P.G.], Montreal Children's Hospital Research Institute, McGill University, Montreal, Quebec H3Z 2Z3, Canada; Department of Mathematics and Statistics [L.L.-C.], University of Laval, Ste-Foy, Quebec G1K 7P4, Canada; McGill University and Genome Quebec Innovation Centre [A.M.], Montreal, Quebec H3A 1A4, Canada
\end{abstract}

\begin{abstract}
Retinoic acid (RA) is a critical regulator of gene expression during embryonic development. In rodents, moderate maternal vitamin A deficiency leads to subtle morphogenetic defects and inactivation of RA pathway genes causes major disturbances of embryogenesis. In this study, we quantified RA in umbilical cord blood of 145 healthy full-term Caucasian infants from Montreal. Sixty seven percent of values were $<10 \mathrm{nmol} / \mathrm{L}$ ( 84 were $<0.07$ $\mathrm{nmol} / \mathrm{L}$ ) and $33 \%$ had moderate or high levels. Variation in RA could not be explained by parallel variation in its precursor, retinol (ROL). However, we found that the (A) allele of the rs12591551 single nucleotide polymorphism (SNP) in the ALDH1A2 gene (ALDH1A2 $2^{\text {rs12591551(A) }}$, occurring in $19 \%$ of newborns, was associated with 2.5 -fold higher serum RA levels. ALDH1A2 encodes retinaldehyde dehydrogenase (RALDH) 2, which synthesizes RA in fetal tissues. We also found that homozygosity for the (A) allele of the rs12724719 SNP in the $C R A B P 2$ gene $\left(C R A B P 2^{\text {rs12724719(A/A) }}\right)$ was associated with 4.4-fold increase in umbilical cord serum RA. $C R A B P 2$ facilitates RA binding to its cognate receptor complex and transfer to the nucleus. We hypothesize that individual variation in RA pathway genes may account for subtle variations in RAdependent human embryogenesis. (Pediatr Res 67: 598-602, 2010)
\end{abstract}

$\mathbf{I}^{\mathrm{n}}$ Western countries, pregnant women consume $\sim 1-2 \mathrm{mg} / \mathrm{d}$ of the provitamin $\mathrm{A}$, beta-carotene, from oranges, green leafy vegetables, and fortified beverages (1). Between 10 and $25 \%$ of this is converted to retinol (ROL) (1), which circulates in maternal blood in the form bound to a dimeric complex containing retinol binding protein (RBP) 4 and transthyretin $(2,3)$.

During passage through the placenta, ROL is transferred to the fetal circulation, where it is picked up by fetal RBP4 or chylomicrons and delivered to fetal tissues $(2,4,5)$. In the fetal tissues, ROL is converted to retinal and then to retinoic acid (RA) by the embryonic retinaldehyde dehydrogenase (RALDH) 2 (6). In mice, targeted disruption of Raldh2 arrests development at midgestation (7-9), whereas administration of

Received November 18, 2009; accepted March 4, 2010.

Correspondence: Paul Goodyer, M.D., Montreal Children's Hospital, 2300 Tupper Street, Montreal, Quebec, Canada H3H 1P3; e-mail: paul.goodyer@mcgill.ca

Supported by Operating Grants MOP 81313 and MOP12954 from the Canadian Institutes of Health Research and an infrastructure support grant to the McGill University Health Centre Research Institute from the Fonds de Recherches en Santé de Québec. R.E.K. is the recipient of a Kidney Foundation of Canada Postdoctoral Research Fellowship. P.G. is the recipient of a CIHR James McGill Research Chair.

D.C.M. and R.E.K. contributed equally to this study. exogenous RA to the mother allows the development of Raldh2 $2^{-1-}$ embryos to proceed (7).

Within fetal tissues, RA may exit the cell or it may be targeted for degradation by binding to cellular retinoic acid binding protein (CRABP) $1(10,11)$. Several studies (12-16) suggest an alternative fate in which RA is transferred to the nucleus via CRABP2 (12-16). In the nucleus, it associates with heterodimeric nuclear receptors $(\operatorname{RAR} \alpha, \beta, \gamma)$ that regulate transcription of target genes (17). Fetal RA is catabolized primarily by CYP26A1, a member of the cytochrome 4450 system $(18,19)$. Mice lacking either Cyp26al or Cyp26bl genes die perinatally and exhibit abnormalities consistent with those seen in RA excess, including spina bifida, truncation of the tail, and abnormalities affecting the kidneys, urogenital tract, and hindgut (20-22).

Despite the vast literature attesting to the powerful effects of RA on embryogenesis and cell physiology, very little is known about the circulating levels of RA among human newborns. Also, there is no appreciable understanding of the factors that influence individual newborn RA level. Here, we report umbilical cord serum RA levels in 145 healthy full-term newborn Caucasian infants from Montreal. We show that RA level is unrelated to serum ROL concentration but that a subset of newborns bearing common variants of $A L D H 1 A 2$ (encoding RALDH2) and CRABP2 genes have significantly elevated levels of umbilical cord RA.

\section{METHODS}

Reagents. The authentic standard retinoids (ROL and RA) were purchased from Sigma Chemical Co.-Aldrich (St-Louis, MO). The purity of the retinoids was verified by HPLC. Retinoids were handled under yellow light to prevent photoisomerization. HPLC-grade solvents were purchased from Fisher Scientific (Toronto, Ontario, Canada).

Study subjects. Healthy Caucasian infants $(n=145)$ who were born to mothers with uncomplicated pregnancies were recruited with informed parental consent at the prenatal clinic visit at the Royal Victoria Hospital

Abbreviations: $\mathbf{A L D H 1 A 2}$, aldehyde dehydrogenase 1 family, member A2; CEPH, Centre d'Étude du Polymorphisme Humain; CRABP1, cellular retinoic acid binding protein 1; $\boldsymbol{C R A B P 2}$, cellular retinoic acid binding protein 2; CYP26A1, cytochrome P450, family 26, subfamily A, polypeptide 1; CYP26B1, cytochrome P450, family 26, subfamily B, polypeptide 1; RA, retinoic acid; RALDH2, retinaldehyde dehydrogenase 2, ROL, retinol; SNP, single nucleotide polymorphism 
(Montreal, Quebec, Canada). The study was approved by the Montreal Children's Hospital Research Ethics Board. Mothers with twins, diabetes, intrauterine growth restriction, genetic abnormalities, or delivery $<36 \mathrm{wk}$ were excluded. Babies with Apgar scores $<7$ at 1 min were excluded.

Cord blood analyses. At birth, cord blood was obtained for isolation of leukocyte DNA and retinoid (ROL and RA) assay. Genomic DNA was isolated with the FlexiGene DNA kit (Qiagen, Mississauga, Ontario, Canada) according to the manufacturer's protocol. DNA was quantified using the Quant-iT PicoGreen dsDNA Assay Kit *2000 (Invitrogen, Carlsbad, CA). To measure retinoids, the cord blood was collected in a 7-mL vacutainer tube containing a silica gel-based clotting activator, previously wrapped with aluminum foil to minimize the exposure to light. The blood was immediately processed in a dark room, and serum was collected by centrifugation at 10,000 rpm at $4^{\circ} \mathrm{C}$. Serum samples were stored in 1.5 - $\mathrm{mL}$ brown cryotubes, coded, and stored at $-80^{\circ} \mathrm{C}$ until analysis.

Extraction of retinoids from cord blood for HPLC analysis. Retinoids from the blood samples were extracted by butanol/acetonitrile (equal volumes) essentially as described by McClean et al. (23), except that the method was adapted to a smaller sample volume. Serum samples stored at $-80^{\circ} \mathrm{C}$ were defrosted on ice and centrifuged for $10 \mathrm{~min}$ at $4^{\circ} \mathrm{C}$ at $3000 \mathrm{rpm}$ to obtain a clear supernatant. Two hundred microliters of serum was transferred to a borosilicate tube wrapped in aluminum foil, and $200 \mu \mathrm{L}$ of butanol/acetonitrile (1:1) was added. The mixture was vortexed for $1 \mathrm{~min}$, and after that, we added to it a salt solution of $72 \mathrm{mg}$ $\mathrm{K}_{2} \mathrm{HPO}_{4} \cdot 3 \mathrm{H}_{2} \mathrm{O}$, previously diluted in $20 \mu \mathrm{L}$ of water $(15.8$ molar and $\mathrm{pH} 9.0)$. Then, the mixture was vortexed again for $30 \mathrm{~s}$. The extraction mixture was centrifuged at $3000 \mathrm{rpm}$ for $15 \mathrm{~min}$ in a Sorvall RC3C Plus centrifuge precooled to $4^{\circ} \mathrm{C}$. One hundred microliters of clear supernatant was injected onto HPLC. Recovery studies were performed with the addition of retinoids $(5-50 \mathrm{ng} / 100 \mu \mathrm{L}$ range) to three separate cord blood samples.

HPLC analysis of retinoids. For retinoid analysis, we used a Shimadzu LC-10ADVP equipped with a SIL-HTC autosampler and cooling system (Man-Tech, Guelph, Ontario, Canada). Retinoids were separated on a Partisil 10-ODS analytical column $(250 \times 4.5 \mathrm{~mm}$; Grace Discovery Sciences, IL) and eluted with a mobile phase of acetonitrile:water (65:35), containing 10 $\mathrm{mM}$ ammonium acetate, at a flow rate of $1.2 \mathrm{~mL} / \mathrm{min}$. Retinoids were detected in a photodiode array detector (Shimadzu Model SPD-M10 AVP), which collected spectra between 200 and $500 \mathrm{~nm}$. Calibration curves for RA and ROL were obtained using standard pure solutions of retinoids. Characteristic UV spectra and retention times identified each retinoid, and peak areas were measured at $\lambda_{\max -330}$ in a Shimadzu SZ-228 data system. The detection limit for retinoids was $2 \mathrm{pg}(0.14 \mathrm{nmol} / \mathrm{L})$.

Choice of single nucleotide polymorphisms. The NCBI dbSNP database was screened for coding and noncoding single nucleotide polymorphism (SNPs) in ALDH1A2, CYP26A1, CYP26B1, CRABP1, and CRABP2 genes with minor allele frequency of $>5 \%$ in Caucasian populations. For each gene, ALDH1A2, CYP26A1, CYP26B1, CRABP1, and CRABP2, the haplotype tagging SNPs were chosen from a region that spanned the entire gene plus 10 $\mathrm{kb}$ at both the $5^{\prime}$ and $3^{\prime}$ flanking segments, using the HapMap human genome database (http://www.hapmap.org/cgi-perl/gbrowse/hapmap_B36/). All known SNPs from the Centre d'Étude du Polymorphisme Humain (CEPH; http://www.cephb.fr) population (white individuals from Western Europe who settled in Utah) for the ALDH1A2, CYP26A1, CYP26B1, CRABP1, and $C R A B P 2$ genes regions were downloaded into Haploview (Haploview version 4.1; http://www.broadinstitute.org/mpg/haploview) (24), and a plot of linkage disequilibrium (LD) between SNPs was obtained. By using Haploview's pairwise "Tagger" program (25), we chose htSNP $\left(r^{2}>0.8\right)$ that occurred in at least $5 \%$ of the population.

SNP genotyping. A total of 135 patients were genotyped. For each subject, $15 \mathrm{ng}$ of genomic DNA was used for multiplex genotyping, using Sequenom iPLEX PCR technology (Sequenom, San Diego, CA). This system involves extension of the PCR amplicon with modified nucleotides to distinguish SNP alleles by matrix-assisted laser desorption ionization-time of flight technology. Primers for SNP detection were designed using MassARRAY Assay Design software (Sequenom).

Statistical methods. We analyzed data with $\mathrm{R}$ software (http://cran.r-project.org; version 2.7.1). Genotype frequencies for each SNP were examined for divergence from Hardy-Weinberg equilibrium. The $\chi^{2}$ test was conducted for genotype analysis. The dependency between RA and ROL was tested by Kendall's tau. Because exact values for RA cannot be known below a certain limit of detection, we adapted the methodology of Oakes (26) to left-censored data to estimate Kendall's tau.

\section{RESULTS}

Characteristics of study subjects. Body measurements were available for 121 babies (53 girls and 68 boys) from the cohort
Table 1. Characteristics of study subjects

\begin{tabular}{lccc}
\hline \multicolumn{1}{c}{ Characteristics } & $\begin{array}{c}\text { Mean } \\
\text { value }(\mathrm{SD})\end{array}$ & $\begin{array}{c}\text { Minimum } \\
\text { value }\end{array}$ & $\begin{array}{c}\text { Maximum } \\
\text { value }\end{array}$ \\
\hline Weight $(\mathrm{kg})$ & $3.57(0.46)$ & 2.62 & 5.05 \\
Height $(\mathrm{cm})$ & $51.20(2.25)$ & 46 & 58 \\
Body surface area $\left(\mathrm{m}^{2}\right)$ & $0.22(0.01)$ & 0.18 & 0.27 \\
\hline
\end{tabular}

The mean and standard deviation (SD) measurements of weight, height, and body surface area are presented for 121 newborns from the cohort for whom complete morphometric data were available.

A

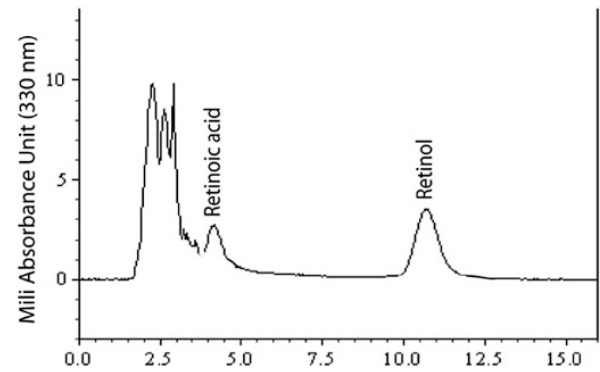

B

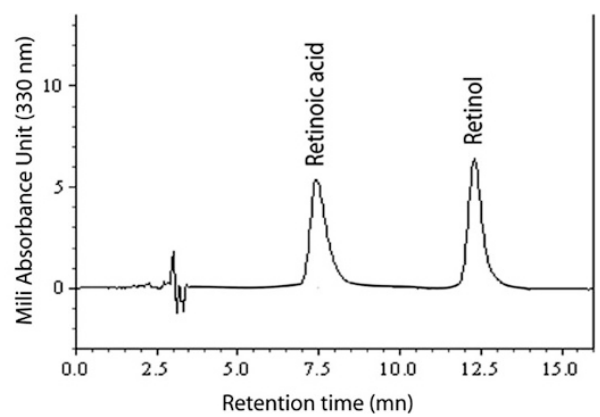

Figure 1. HPLC chromatogram of umbilical cord serum sample $(A)$ and standard retinoids $(B)$. RA and ROL are present and well separated.

(Table 1). Mean $( \pm \mathrm{SD})$ newborn weight, height, and body surface area (BSA) were $3.57 \pm 0.46 \mathrm{~kg}, 51.2 \pm 2.25 \mathrm{~cm}$, and $0.22 \pm 0.01 \mathrm{~m}^{2}$, respectively.

Retinoid levels in cord blood. Numerous retinoids, in addition to ROL and retinyl esters, are present in plasma at nanomolar concentrations $(\sim 5-10 \mathrm{nM})$. These include alltrans RA, 13-cis RA, 13-cis-4-oxo RA, and others $(27,28)$. We optimized an extraction procedure adapted to HPLC separation (23) for measuring RA in cord blood of 145 infants in Montreal. Figure $1 A$ shows an HPLC chromatogram of an umbilical cord serum sample. RA and ROL were present and well separated, and their presence was confirmed by characteristic UV absorption maxima (data not shown). In this HPLC system, the isomers of RA such as 13-cis/9-cis are not separated, and therefore the retinoids eluting as peak 1 constitute a mixture of RAs. Note that in Figure 1A, there is a shift in the elution times of RA and ROL compared with the elution times of standard retinoids (Fig. 1B). This could be due to the presence of lipids in the cord blood, which interfere with interactions between retinoids and column materials. Addition of dipotassium phosphate to the extraction mixture enhanced the recovery of retinoids. Recovery studies, with known amounts of retinoids added to the blood samples, resulted in yields of RA and ROL of $>99 \%$. However, repeated freezing and thawing of the blood samples resulted in significant loss of retinoids. Storage of blood samples 
at $-20^{\circ} \mathrm{C}$ for 1 year resulted in $63 \%$ loss of retinoids. Samples for this study were stored at $-80^{\circ} \mathrm{C}$; at this temperature, degradation of retinoids is minimal.

Marked variation in RA levels $(0.07-550 \mathrm{nmol} / \mathrm{L})$ was observed in the 145 cord samples analyzed. The distribution was skewed, with the appearance of three distinct subgroups: 1) two thirds of the samples (97 infants) fell below a RA concentration of $10 \mathrm{nmol} / \mathrm{L}$ and, in most (84 infants), RA was below the limit of detection $(0.07 \mathrm{nmol} / \mathrm{L}) ; 2)$ RA concentrations in $28 \%$ of samples were spread between 10 and 100 nmol/L; 3) in $5 \%$ of samples (eight infants), RA concentrations were substantially higher (100-550 nmol/L; Fig. 2). The skewed distribution of umbilical cord RA could not be explained by parallel variation in its precursor, ROL. ROL was normally distributed, with an average of $1150 \mathrm{nmol} / \mathrm{L}$ and values ranging

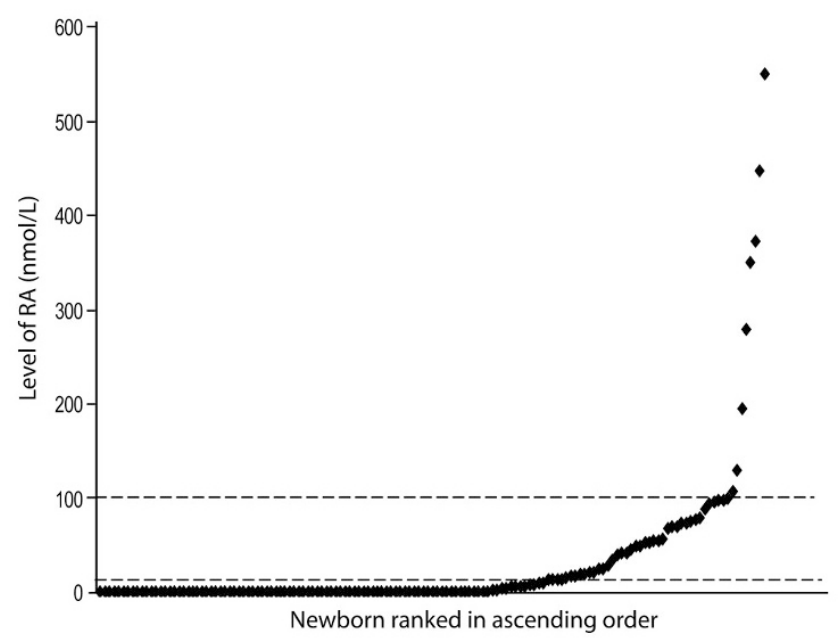

Figure 2. Distribution of umbilical cord RA levels in full-term newborns. The distribution of umbilical cord RA levels in our cohort was skewed, with the appearance of three distinct subgroups: $67 \%$ of the samples fell below 10 $\mathrm{nmol} / \mathrm{L}$ (group 1); 28\% of samples were between 10 and $100 \mathrm{nmol} / \mathrm{L}$ (group 2); $5 \%$ were $>100 \mathrm{nmol} / \mathrm{L}$ (group 3 ).

Table 2. Umbilical cord serum ROL levels in the three RA groups

\begin{tabular}{lccc}
\hline & $\begin{array}{c}\text { Group 1 } \\
\text { (RA }<10 \\
\text { nmol/L) }\end{array}$ & $\begin{array}{c}\text { Group 2 } \\
(10 \mathrm{nmol} / \mathrm{L}<\mathrm{RA} \\
<100 \mathrm{nmol} / \mathrm{L})\end{array}$ & $\begin{array}{c}\text { Group 3 } \\
(\mathrm{RA}>100 \mathrm{nmol})\end{array}$ \\
\hline No. newborns & 97 & 40 & 8 \\
Percentage & 67 & 28 & 5 \\
Mean ROL & $1294(75)$ & $793(96)$ & $1194(126)$ \\
$\quad$ levels (SEM) & & & \\
\hline
\end{tabular}

Mean $( \pm$ SEM) ROL levels $(\mathrm{nmol} / \mathrm{L})$ in the three RA groups are presented. between 51.4 and $3892 \mathrm{nmol} / \mathrm{L}$. Mean cord ROL levels in the three subgroups were $1294 \mathrm{nmol} / \mathrm{L}$ (group 1) $793 \mathrm{nmol} / \mathrm{L}$ (group 2), and $1194 \mathrm{nmol} / \mathrm{L}$ (group 3), respectively (Table 2). In fact, there was weak inverse correlation between ROL and RA levels (Kendall tau $=-0.2733, p<0.01$ ).

Association between cord RA and SNPs in genes encoding enzymes of $\boldsymbol{R A}$ synthesis and degradation. Because the skewed distribution of RA levels could not be explained by variation in ROL, we explored the possibility that circulating levels of RA were influenced by variation in genes involved in RA synthesis (ALDH1A2) or degradation (CYP26A1; CYP26B1). Each subject was genotyped for SNPs spanning each candidate gene. SNP frequencies were similar to those of the HapMap Caucasian $(\mathrm{CEPH})$ population, indicating no appreciable genetic drift in our cohort. Genotype distributions for each SNP locus conformed to Hardy-Weinberg predictions. By using a $\chi^{2}$ test, we found that heterozygous $A L D H 1 A 2^{\text {rs } 12591551(\mathrm{~A} / \mathrm{C})}$ babies (19\% of the cohort) are associated with high values of umbilical cord serum RA ( $p=$ 0.035; Table 3). In fact, heterozygous (rs12591551C/A) babies showed a 2.5-fold increase in cord RA (62.2 nmol/L) compared with subjects who were homozygous for the wildtype allele (rs12591551C/C; $25 \mathrm{nmol} / \mathrm{L})$. None of the SNPs within the CYP26A1 and CYP26B1 genes showed significant association with RA levels.

Association between RA and SNPs in genes encoding intracellular $\boldsymbol{R} \boldsymbol{A}$ binding proteins. We also considered the possibility that circulating levels of RA in the fetus were influenced by variation in genes encoding intracellular RA binding proteins (CRABP1 and CRABP2). We chose htSNPs and cSNPs in the $\mathrm{CEPH}$ population, and all subjects were genotyped at these loci; SNP frequencies in our cohort were similar to those of the CEPH population, indicating no appreciable genetic drift. Genotype distributions for each SNP locus conformed to the expected Hardy-Weinberg equilibrium.

By using the $\chi^{2}$ test, we identified an association between the $C R A B P 2^{\text {rs12724719A/A }}$ genotype and higher levels of RA ( $p=0.013$; Table 3$)$. Homozygous $C R A B P 2^{\text {rs } 12724719 \mathrm{~A} / \mathrm{A}}$ newborns ( $3 \%$ of the population) showed a 4.4-fold increase (141.3 versus $32.3 \mathrm{nmol} / \mathrm{L}$ ) of umbilical cord serum RA compared with homozygous $C R A B P 2^{\text {rs } 12724719 \mathrm{G} / \mathrm{G}}$ babies (75\% of the population).

\section{DISCUSSION}

Fetal RA is derived from fetal metabolism of maternally supplied ROL in developing tissues (29). We used a refined

Table 3. Genotype distribution in the three RA groups

\begin{tabular}{|c|c|c|c|c|c|c|c|}
\hline Gene & SNP & Genotype & $\begin{array}{c}\mathrm{RA}<10 \mathrm{nmol} / \mathrm{L}, \\
n(\%)\end{array}$ & $\begin{array}{c}10 \mathrm{nmol} / \mathrm{L}<\mathrm{RA} \\
<100 \mathrm{nmol} / \mathrm{L}, \\
n(\%)\end{array}$ & $\begin{array}{c}\mathrm{RA}>100 \mathrm{nmol} / \mathrm{L}, \\
n(\%)\end{array}$ & $\chi^{2}$ & $p$ \\
\hline \multirow{2}{*}{$A L D H 1 A 2$} & rs12591559 & $\mathrm{CC}$ & $77(71)$ & $27(25)$ & $5(4)$ & 6.72 & 0.035 \\
\hline & & $\mathrm{CA}$ & $11(44)$ & $11(44)$ & $3(12)$ & & \\
\hline \multirow[t]{3}{*}{$C R A B P 2$} & rs12724719 & GG & $71(72)$ & $21(21)$ & $7(7)$ & 18.61 & 0.013 (GG vs AA) \\
\hline & & $\mathrm{AG}$ & $16(53)$ & $14(47)$ & $0(0)$ & & \\
\hline & & AA & $1(25)$ & $2(50)$ & $1(25)$ & & \\
\hline
\end{tabular}

Heterozygous $A L D H 1 A 2^{\text {rs } 12591551 \mathrm{C} / \mathrm{A}}$ babies showed a 2.5-fold increase in cord RA compared with subjects who were homozygous for the wildtype allele $A L D H 1 A 2^{\text {rs } 12591551 \mathrm{C} / \mathrm{C}}$. Homozygous $C R A B P 2^{\text {rs } 12724719 \mathrm{~A} / \mathrm{A}}$ newborns showed a 4.4-fold increase of umbilical cord serum RA compared with homozygous CRABP2 $2^{\text {rs 12724719G/G }}$ babies. 
HPLC method to measure RA levels in umbilical cord blood of healthy full-term newborn Montreal babies. Interestingly, the majority of infants had low circulating RA level $(<10$ $\mathrm{nmol} / \mathrm{L}$ ). However, the distribution of RA levels in our cohort was skewed by two apparent subpopulations of newborns with much higher RA levels ranging from $10-100 \mathrm{nmol} / \mathrm{L}$ and $>100 \mathrm{nmol} / \mathrm{L}$, respectively. Berggren Soderlund et al. (30) measured RA levels in umbilical cord blood from 10 Swedish newborns $($ mean $=3.4 \mathrm{nmol} / \mathrm{L}$ ). However, the reported range of RA values was much narrower than in our study. Conceivably, our identification of a subgroup with significantly higher RA levels was because of our improved extraction method. None of the mothers in our cohort were taking supplementary retinoids.

Although fetal RA is generated in fetal tissues from maternally supplied ROL, we found no relationship between umbilical cord RA and the corresponding level of umbilical cord ROL. This result is concordant with the findings of Berggren Soderlund et al. (30). Therefore, we reasoned that individual variation in newborn blood RA likely reflects variation in fetal genes involved in ROL metabolism, RA degradation, or RA delivery to the nucleus where it exerts its effects on transcription of target genes.

After its uptake by fetal tissues, ROL is reversibly converted to retinal by alcohol dehydrogenase and then irreversibly to alltrans RA by RALDH2. Because the latter is the rate-limiting step, we investigated whether fetal RA levels might be influenced by common variants of the human ALDHIA2 gene. We screened a panel of SNPs spanning the ALDH1A2 locus and found that newborns heterozygous $(\mathrm{A} / \mathrm{C})$ for the $A L D H 1 A 2^{\text {rs } 12591551} \mathrm{SNP}$ (intron 7) had a 2.5-fold increase in umbilical cord RA level compared with those who were homozygous for the wildtype allele, $A L D H 1 A 2^{\text {rs } 12591551(\mathrm{C})}$. Approximately $19 \%$ of our healthy full-term newborns were heterozygous for this variant allele, demonstrating that is a fairly common normal variant and might confer a biologic advantage in settings where maternal ROL availability is marginal.

The ALDH1A2 $2^{\text {rs } 12591551}$ SNP is located in intron 7. Interestingly, Cawley et al. (31) have shown that $\sim$ one third of the transcription factor binding sites that regulate gene expression lie within introns or $3^{\prime}$ to the coding sequence. Thus, the $A L D H 1 A 2^{\text {rs12591551 }}$ may mark a variant regulatory sequence, which enhances RALDH2 expression in fetal tissues, increases intracellular RA pools, and, thereby, raises circulating RA levels in cord blood. It seems unlikely that umbilical cord RA level is determined by the maternal ALDH1A2 genotype, because this gene is expressed primarily in fetal tissues (7).

Intracellular RA bound to CRABP1 is targeted for degradation in fetal tissues by CYP26A1 and CYP26B1 members of the cytochrome $\mathrm{P} 450$ system (32). This pathway is clearly a powerful regulator of the intracellular RA pool in fetal tissues. Mice with inactivation of Cyp26Al or Cyp26B1 genes die in utero (33). However, these genes are highly conserved, and no common variants of these two human CYPs were associated with umbilical cord RA in our cohort.

Intracellular RA may also bind to CRABP2, which facilitates delivery to the nucleus $(12,34)$, where it activates RAR transcriptional regulation of target genes (35). In our cohort, the four babies who were homozygous for the $C R A B P 2^{\text {rs } 12724719 \mathrm{~A}}$ variant had substantially increased levels of cord blood RA compared with newborns who were homozygous for the wildtype $G$ allele (141.3 versus 32.3 $\mathrm{nmol} / \mathrm{L}$, respectively). However, newborns who were heterozygous $\left(C R A B P 2^{\mathrm{rs} 12724719 \mathrm{~A} / \mathrm{G}}\right)$ for the SNP had levels of umbilical cord RA similar to wildtypes. We speculate that the $C R A B P 2^{\text {rs } 12724719 \mathrm{~A}}$ allele is slightly dysfunctional in the homozygous state and reduces the level of CRABP2 expression, thereby compromising delivery of RA to the nucleus. Because reduced RA signaling induces feedback up-regulation of RALDH2 expression (36), this might increase RA level in fetal tissues and, consequently, in umbilical cord RA.

Our studies show for the first time that the distribution of RA level in human neonates is skewed by the presence of two subgroups with relatively high RA. We found that this is unrelated to the availability of circulating ROL substrate but is affected by fetal genotype for variant alleles of the ALDH1A2 and $C R A B P 2$ genes.

\section{REFERENCES}

1. Strobel M, Tinz J, Biesalski HK 2007 The importance of beta-carotene as a source of vitamin A with special regard to pregnant and breastfeeding women. Eur J Nutr 46:I1-I20

2. Ross SA, McCaffery PJ, Drager UC, De Luca LM 2000 Retinoids in embryonal development. Physiol Rev 80:1021-1054

3. Monaco HL, Rizzi M, Coda A 1995 Structure of a complex of two plasma proteins: transthyretin and retinol-binding protein. Science 268:1039-1041

4. Gudas LJ 1994 Retinoids and vertebrate development. J Biol Chem 269:1539915402

5. Clagett-Dame M, DeLuca HF 2002 The role of vitamin A in mammalian reproduction and embryonic development. Annu Rev Nutr 22:347-381

6. Wang X, Penzes P, Napoli JL 1996 Cloning of a cDNA encoding an aldehyde dehydrogenase and its expression in Escherichia coli. Recognition of retinal as substrate. J Biol Chem 271:16288-16293

7. Niederreither K, Subbarayan V, Dolle P, Chambon P 1999 Embryonic retinoic acid synthesis is essential for early mouse post-implantation development. Nat Genet 21:444-448

8. Niederreither K, Vermot J, Schuhbaur B, Chambon P, Dolle P 2000 Retinoic acid synthesis and hindbrain patterning in the mouse embryo. Development 127:75-85

9. Niederreither K, Vermot J, Messaddeq N, Schuhbaur B, Chambon P, Dolle P 2001 Embryonic retinoic acid synthesis is essential for heart morphogenesis in the mouse. Development 128:1019-1031

10. Boylan JF, Gudas LJ 1991 Overexpression of the cellular retinoic acid binding protein-I (CRABP-I) results in a reduction in differentiation-specific gene expression in F9 teratocarcinoma cells. J Cell Biol 112:965-979

11. Boylan JF, Gudas LJ 1992 The level of CRABP-I expression influences the amounts and types of all-trans-retinoic acid metabolites in F9 teratocarcinoma stem cells. J Biol Chem 267:21486-21491

12. Jing Y, Waxman S, Mira-y-Lopez R 1997 The cellular retinoic acid binding protein II is a positive regulator of retinoic acid signaling in breast cancer cells. Cancer Res 57:1668-1672

13. Bastie JN, Despouy G, Balitrand N, Rochette-Egly C, Chomienne C, Delva L 2001 The novel co-activator CRABPII binds to RARalpha and RXRalpha via two nuclear receptor interacting domains and does not require the AF-2 'core'. FEBS Lett 507:67-73

14. Budhu A, Gillilan R, Noy N 2001 Localization of the RAR interaction domain of cellular retinoic acid binding protein-II. J Mol Biol 305:939-949

15. Budhu AS, Noy N 2002 Direct channeling of retinoic acid between cellular retinoic acid-binding protein II and retinoic acid receptor sensitizes mammary carcinoma cells to retinoic acid-induced growth arrest. Mol Cell Biol 22:2632-2641

16. Dong D, Ruuska SE, Levinthal DJ, Noy N 1999 Distinct roles for cellular retinoic acid-binding proteins I and II in regulating signaling by retinoic acid. J Biol Chem 274:23695-23698

17. Bailey JS, Siu CH 1988 Purification and characterization of a murine cellular retinoic acid-binding protein. Biochem Cell Biol 66:750-757

18. Abu-Abed S, Dolle P, Metzger D, Wood C, MacLean G, Chambon P, Petkovich M 2003 Developing with lethal RA levels: genetic ablation of Rarg can restore the viability of mice lacking Cyp26a1. Development 130:1449-1459

19. Marlier A, Gilbert T 2004 Expression of retinoic acid-synthesizing and -metabolizing enzymes during nephrogenesis in the rat. Gene Expr Patterns 5:179-185

20. Abu-Abed S, Dolle P, Metzger D, Beckett B, Chambon P, Petkovich M 2001 The retinoic acid-metabolizing enzyme, CYP26A1, is essential for normal hindbrain patterning, vertebral identity, and development of posterior structures. Genes Dev $15: 226-240$ 
21. Sakai Y, Meno C, Fujii H, Nishino J, Shiratori H, Saijoh Y, Rossant J, Hamada H 2001 The retinoic acid-inactivating enzyme CYP26 is essential for establishing an uneven distribution of retinoic acid along the anterio-posterior axis within the mouse embryo. Genes Dev 15:213-225

22. Yashiro K, Zhao X, Uehara M, Yamashita K, Nishijima M, Nishino J, Saijoh Y, Sakai Y, Hamada H 2004 Regulation of retinoic acid distribution is required for proximodistal patterning and outgrowth of the developing mouse limb. Dev Cell 6:411-422

23. McClean SW, Ruddel ME, Gross EG, DeGiovanna JJ, Peck GL 1982 Liquidchromatographic assay for retinol (vitamin A) and retinol analogs in therapeutic trials. Clin Chem 28:693-696

24. Barrett JC, Fry B, Maller J, Daly MJ 2005 Haploview: analysis and visualization of LD and haplotype maps. Bioinformatics 21:263-265

25. de Bakker PI, Yelensky R, Pe'er I, Gabriel SB, Daly MJ, Altshuler D 2005 Efficiency and power in genetic association studies. Nat Genet 37:1217-1223

26. Oakes D 1982 A concordance test for independence in the presence of censoring. Biometrics 38:451-455

27. Wyss R, Bucheli F 1997 Determination of endogenous levels of 13-cis-retinoic acid (isotretinoin), all-trans-retinoic acid (tretinoin) and their 4-oxo metabolites in human and animal plasma by high-performance liquid chromatography with automated column switching and ultraviolet detection. J Chromatogr B Biomed Sci Appl 700:31-47

28. Barua AB, Sidell N 2004 Retinoyl beta-glucuronide: a biologically active interesting retinoid. J Nutr 134:286S-289S
29. Ross AC, Gardner EM 1994 The function of vitamin A in cellular growth and differentiation, and its roles during pregnancy and lactation. Adv Exp Med Biol 352:187-200

30. Berggren Soderlund M, Fex GA, Nilsson-Ehle P 2005 Concentrations of retinoids in early pregnancy and in newborns and their mothers. Am J Clin Nutr 81:633-636

31. Cawley S, Bekiranov S, Ng HH, Kapranov P, Sekinger EA, Kampa D, Piccolboni A, Sementchenko V, Cheng J, Williams AJ, Wheeler R, Wong B, Drenkow J, Yamanaka M, Patel S, Brubaker S, Tammana H, Helt G, Struhl K, Gingeras TR 2004 Unbiased mapping of transcription factor binding sites along human chromosomes 21 and 22 points to widespread regulation of noncoding RNAs. Cell 116:499-509

32. MacLean G, Abu-Abed S, Dolle P, Tahayato A, Chambon P, Petkovich M 2001 Cloning of a novel retinoic-acid metabolizing cytochrome P450, Cyp26B1, and comparative expression analysis with Cyp26A1 during early murine development. Mech Dev 107:195-201

33. Abu-Abed S, MacLean G, Fraulob V, Chambon P, Petkovich M, Dolle P 2002 Differential expression of the retinoic acid-metabolizing enzymes CYP26A1 and CYP26B1 during murine organogenesis. Mech Dev 110:173-177

34. Takase S, Ong DE, Chytil F 1986 Transfer of retinoic acid from its complex with cellular retinoic acid-binding protein to the nucleus. Arch Biochem Biophys 247:328-334

35. Chambon P 1996 A decade of molecular biology of retinoic acid receptors. FASEB J 10:940-954

36. Dobbs-McAuliffe B, Zhao Q, Linney E 2004 Feedback mechanisms regulate retinoic acid production and degradation in the zebrafish embryo. Mech Dev 121:339-350 